Jurnal Ilmiah Ibnu Sina, 5(1), Maret 2020, 72-86

p-ISSN: 2502-647X; e-ISSN: 2503-1902

\title{
PENGARUH PENGETAHUAN-SIKAP MENGENAI VITAMIN D TERKAIT OBESITAS PADA MAHASISWA
}

\author{
Amelia Lorensia $^{1 *}$, Dian Natasya Raharjo ${ }^{1}$, Novelia Gandawari ${ }^{2}$ \\ ${ }^{1}$ Departemen Farmasi Klinis-Komunitas, Fakultas Farmasi, Universitas Surabaya \\ ${ }^{2}$ Fakultas Farmasi, Universitas Surabaya \\ *Email: amelia.lorensia@gmail.com
}

Artikel diterima: 12 Oktober 2019; Disetujui: 26 Februari 2020

DOI: https://doi.org/10.36387/jiis.v5i1.388

\begin{abstract}
ABSTRAK
Indonesia sebagai negara tropis tetapi masyarakatnya kecenderungan mengalami defisiensi vitamin D. Pengetahuan dan sikap terhadap paparan sinar matahari berperan mempengaruhi risiko defisensi vitamin D. Di tengah pola hidup perkotaan, obesitas juga meningkatkan risiko defisiensi vitamin D. Penelitian ini dilakukan untuk mengetahui pengaruh tingkat pengetahuan dan sikap mengenai vitamin D terkait obesitas pada dewasa, yang dilakukan pada Maret 2018 sampai dengan Januari 2019. Penelitian menggunakan desain cross sectional, dengan kuesioner pengetahuan dan sikap mengenai vitamin D. Responden berusia dewasa dan berdomosili di Surabaya, sebanyak 74 orang pada masing-masing kelompok obesitas dan non-obesitas. Hasil penelitian menunjukkan bahwa responden obesitas dan non-obesitas sama-sama memiliki pengetahuan baik (OR 1,138) namun memiliki sikap yang buruk (OR 1,000). Tidak ada perbedaan signifikan pengetahuan dan sikap pada kedua kelompok, dan memiliki korelasi yang lemah.
\end{abstract}

Kata kunci: Pengetahuan, sikap, vitamin D, obesitas, dewasa

\begin{abstract}
Indonesia as a tropical country has a tendency to experience vitamin $D$ deficiency. Knowledge and attitudes towards sun exposure contribute to the risk of vitamin $D$ deficiency. In the midst of urban life patterns, obesity also increases the risk of vitamin D deficiency. This study was conducted to determine the effect of the level of knowledge and attitudes regarding vitamin D related to obesity in adults, which was conducted in March 2018 to January 2019. The study used a cross sectional design, with a knowledge and attitude questionnaire regarding vitamin $D$. Respondents were adults and domiciled in Surabaya, as many as 74 people in each group of obesity and non-obese. The results showed that obese and non-obese respondents both had good knowledge (OR 1.138) but had a bad attitude (OR 1,000). There was no significant difference in knowledge and attitudes in the two groups, and had a weak correlation.
\end{abstract}

Keywords: Knowledge, attitude, vitamin D, obesity, adult 
Jurnal Ilmiah Ibnu Sina, 5(1), Maret 2020, 72-86

p-ISSN: 2502-647X; e-ISSN: 2503-1902

\section{PENDAHULUAN}

Obesitas pada orang dewasa terjadi karena kecenderungan kurang mengekspos kulit di bawah sinar matahari serta memiliki lemak dalam tubuh yang banyak sehingga risiko defisiensi vitamin D pada orang dewasa akibat obesitas lebih besar daripada non-obesitas (Vanlint, 2013). Kurang terpapar sinar matahari merupakan salah satu pemicu defisiensi vitamin $\mathrm{D}$, seperti penggunaan pakaian yang menutupi seluruh tubuh (Muhairi et al., 2013), dan penggunaan tabir surya (Walker $e t$ al., 2014). Peningkatan obesitas diiringi dengan peningkatan risiko berbagai penyakit, seperti penyakit kardiovaskular, diabetes dan gangguan muskuloskeletal. Obesitas dan status vitamin D memiliki hubungan yang konsisten (Vimaleswaran et al., 2013). Paparan sinar matahari juga mempengaruhi proses metabolisme dari kegemukan pada seseorang (Fleury et al., 2016). Peningkatan indeks masa tubuh dapat menyebabkan penurunan kadar vitamin D dalam tubuh (Vanlint, 2013).
Perubahan gaya hidup karena moderenisasi serta ketakutan kulit berubah menjadi gelap yang mendorong mahasiswa untuk menghindari paparan sinar matahari serta menggunakan tabir surya (Arora et al., 2016). Pada penelitian sebelumnya di Surabaya pada masyarakat usia dewasa menunjukkan bahwa semua responden memiliki kadar vitamin $\mathrm{D}$ dibawah normal yaitu $>30 \mathrm{ng} / \mathrm{mL}$. Oleh karena itu, diperlukan peningkatan pengetahuan akan pentingnya vitamin $\mathrm{D}$, sehingga terjadi perubahan perilaku melalui perbaikan gaya hidup, pola makan dan aktivitas fisik pada masyarakat (Suryadinata et al., 2017).

Upaya untuk mengatasi defisiensi vitamin D seperti menggunakan suplemen tidak cukup, karena harus diimbangi dengan pengetahuan dan sikap yang benar terhadap vitamin D (Qureshi et al., 2015). Pengetahuan tentang vitamin D bisa mempengaruhi status vitamin $\mathrm{D}$ di dalam tubuh (Kung dan Lee, 2006). Pengetahuan tentang manfaat dan sumber dari vitamin D misalnya waktu yang tepat untuk memperoleh vitamin D dari sinar matahari dapat 
Jurnal Ilmiah Ibnu Sina, 5(1), Maret 2020, 72-86

p-ISSN: 2502-647X; e-ISSN: 2503-1902

menurunkan risiko defisiensi vitamin

D. Penelitian yang dilakukan oleh Qureshi et al. (2015) pada mahasiswa kedokteran dari berbagai universitas yang terletak di Karaci, Pakistan menunjukkan bahwa mereka mengetahui gejala dan penyebab dari defisiensi vitamin $\mathrm{D}$, tetapi mayoritas dari mereka tidak ingin terpapar sinar matahari, sedangkan sisanya tidak mengetahui waktu yang efisien untuk memperoleh vitamin $\mathrm{D}$ dari sinar matahari. Hal ini menunjukkan bahwa sikap menjadi penentu utama status vitamin $\mathrm{D}$ di negara-negara dengan sinar matahari yang berlimpah (Nimitphong dan Holick, 2013). Sikap dapat ditumbuh kembangkan melalui proses belajar, artinya sikap dapat dipengaruhi oleh pengetahuan sehingga apabila pengetahuan ditingkatkan maka sikap yang baik terhadap vitamin $\mathrm{D}$ juga akan meningkat (Qureshi et al., 2015).

Penelitian ini bertujuan untuk mengetahui pengaruh tingkat pengetahuan dan sikap mengenai vitamin D terkait obesitas pada dewasa. Tujuan tersebut dipernici menjadi: (a) mengetahui tingkat pengetahuan dan sikap mengenai vitamin D pada dewasa dengan obesitas dan non-obesias; (b) membandingkan pengetahuan dan sikap mengenai vitamin $\mathrm{D}$ dari kelompok dewasa obesitas dan nonobesitas; dan (c) mengetahui hubungan pengetahuan dan sikap mengenai vitamin D pada kelompok dewasa obesitas dan non-obesitas.

\section{METODE PENELITIAN}

Desain penelitian yang digunakan dalam penelitian ini adalah cross sectional dan pengambilan data dilakukan melalui kuesioner.

Subjek penelitian dibagi menjadi dua kelompok, yaitu kelompok pasien dewasa dengan obesitas dan pasien dewasa nonobesitas. Obesitas didefinisikan sebagai akumulasi lemak abnormal (berlebih) yang dapat menggangu kesehatan. Seorang dapat dikatakan obesitas jika IMT (indeks massa tubuh) $>30 \mathrm{~kg} / \mathrm{m}^{2}$ dan dikatakan kelebihan berat badan jika IMT $\geq 25$ $\mathrm{kg} / \mathrm{m}^{2}$ (WHO, 2016).

Populasi penelitian mahasiswa usia dewasa (17-25 tahun) dengan obesitas dan non-obesitas di Surabaya. Responden yang bersedia 
Jurnal Ilmiah Ibnu Sina, 5(1), Maret 2020, 72-86

p-ISSN: 2502-647X; e-ISSN: 2503-1902

berpartisipasi dalam penelitian dan tidak memiliki gangguan fisik-mental (tidak memiliki gangguan mental/cacat sehingga tidak bisa menjalani penelitian dengan baik, tidak memiliki gangguan kulit), dijadikan sebagai sampel dalam penelitian ini.

Teknik pengambilan sampel yaitu dengan cara sampling purposive sampling. Kelompok obesitas dengan IMT $\geq 25,0 \mathrm{~kg} / \mathrm{m}^{2}$ dan non-obesitas dengan IMT $\leq 24,9 \mathrm{~kg} / \mathrm{m}^{2}$. Besar sampel yang digunakan dalam penelitian ialah minimal 76 orang tiap kelompok. Metode perhitungan sampel menggunakan rumus:

dengan:

$$
n=\frac{Z^{2} x p(1-p)}{d^{2}}
$$

$\mathrm{n}$ : besar sampel minimal;

$\mathrm{Z}_{1-\alpha / 2}$ : derajat kemaknaan 1,96 (untuk $\alpha=0,05)$;

$\mathrm{p}$ : proporsi variabel yang ingin diteliti; d: derajat penyimpangan terhadap populasi yang diinginkan.

Nilai p yang digunakan ialah $27,3 \%$, yang merupakan data penduduk obesitas di Kota Surabaya, Jawa Timur. Jadi $p=0,273$ (Riskesdas, 2013). Maka besar sampel penelitian (n) minimal tiap kelompok penelitian sebesar 76 orang

\section{Metode Pengumpulan dan Analisis Data}

Penelitian dilakukan dengan mengumpulkan data melalui kuisioner dan wawancara singkat untuk mengetahui pengetahuan dan sikap mengenai vitamin $\mathrm{D}$ pada dewasa obesitas dibandingkan dengan nonobesitas. Kuesioner yang digunakan merupakan adopsi dari penelitian sebelumnya (Suryadinata et al., 2017; Bolek-Berquist et al., 2009; Zhou et al., 2016).

Data yang diperoleh melalui dua kuesioner yaitu kuesioner pengetahuan dan sikap mengenai vitamin D pada dewasa obesitas dan non-obesitas terkait, kemudian dilakukan uji korelasi untuk melihat hubungan antara pengetahuan dan sikap mengenai vitamin D pada dewasa obesitas dan non-obesitas. Penelitian ini telah lolos uji etik no. 034/KE/I/2018 dari Universitas Surabaya.

Pada penelitian ini analisa dilakukan dengan uji odds ratio untuk mengukur hubungan pengetahuansikap vitamin D dengan obesitas. Lalu dilanjutkan dengan uji chi-square untuk melihat apakah ada perbedaan 
Jurnal Ilmiah Ibnu Sina, 5(1), Maret 2020, 72-86

p-ISSN: 2502-647X; e-ISSN: 2503-1902

signifikan pengetahuan dan sikap pada responden obesitas dan non-obesitas.

\section{HASIL DAN PEMBAHASAN}

\section{Pelaksanaan Penelitian}

Pelaksanaan

penelitian

dilakukan pada bulan Maret 2018

sampai Januari 2019 dengan cara

membagikan kuesioner untuk

mengukur pengetahuan dan sikap

mengenai vitamin D pada responden

obesitas dan non-obesitas, dengan

status mahasiswa di suatu universitas

di Surabaya. Data yang diperoleh

dalam penelitian sebanyak 148

responden yang terdiri dari 74

responden obesitas dan responden non-obesitas.

\section{Uji Validasi dan Reliabilitas}

\section{Kuesioner}

Kuesioner digunakan dalam penelitian, terlebih dahulu dilakukan uji validitas yang terdiri dari validitas internal untuk melihat kesesuaian bahasa dimana kuesioner yang digunakan merupakan adobsi dari kuesioner yang menggunakan Bahasa Inggris. Validitas internal dilakukan pada ketiga ahli dalam bidang farmasi klinik komunitas, kemudian dilanjutkan dengan validasi eksternal untuk melihat kesesuaian isi kuesioner yang dilakukan pada 30 responden yang berada Universitas Surabaya yang aktif berkuliah. Uji validitas dan reliabilitas dilakukan pada aspek pengetahuan dan sikap mengenai vitamin D menggunakan software SPSS versi 24 for windows.

Hasil uji validitas kuesioner pengetahuan mengenai vitamin $\mathrm{D}$ dinyatakan valid $\left(\mathrm{r}_{\text {hitung }}>\mathrm{r}_{\text {tabel }}\right.$ product moment), dimana nilai $\mathrm{r}$ tabel untuk 30 responden 0,361 dan semua item pertanyaan dari kuesioner tersebut memiliki nilai di atas nilai $r_{\text {tabel }}$ product moment. Hasil uji reliabilitas kuesioner pengetahuan mengenai vitamin D dinyatakan reliabel $(0,709)$, karena memiliki nilai Cronbach Alpha 0,61-0,80.

Hasil uji validitas kuesioner sikap terhadap paparan sinar matahari mengenai vitamin D dinyatakan valid. Kuesioner dapat dikatakan valid jika ( $\mathrm{r}_{\text {hitung }}>\mathrm{r}_{\text {tabel }}$ product moment), dimana nilai $r$ tabel untuk 30 responden 0,361 dan semua item pertanyaan dari kuesioner tersebut memiliki nilai di atas nilai $\mathrm{r}$ tabel product moment. Hasil uji reliabilitas kuesioner sikap mengenai vitamin $\mathrm{D}$ dinyatakan 
Jurnal Ilmiah Ibnu Sina, 5(1), Maret 2020, 72-86

p-ISSN: 2502-647X; e-ISSN: 2503-1902

reliabel $(0,704)$ karena memiliki nilai

Cronbach Alpha 0,61-0,80.

\section{Karakteristik Responden}

Tabel 1. Distribusi frekuensi karakteristik pada kelompok obesitas dan nonobesitas

\begin{tabular}{|c|c|c|c|c|c|c|}
\hline & \multirow{3}{*}{\multicolumn{2}{|c|}{ Karakteritik }} & \multicolumn{4}{|c|}{ Kelompok } \\
\hline & & & \multicolumn{2}{|c|}{ Obesitas } & \multicolumn{2}{|c|}{ Non-Obesitas } \\
\hline & & & $\begin{array}{l}\text { Frekuensi } \\
\text { (n: 74) }\end{array}$ & $\begin{array}{c}\text { Persentase } \\
(\%)\end{array}$ & $\begin{array}{c}\text { Frekuensi } \\
\text { (n: 74) }\end{array}$ & $\begin{array}{c}\text { Persentase } \\
(\%)\end{array}$ \\
\hline Jenis & Perempuan & & 34 & 45,95 & 54 & 72,97 \\
\hline Kemain & Laki-laki & & 40 & 54,05 & 20 & 27,03 \\
\hline $\begin{array}{c}\text { Usia } \\
\text { (tahun) }\end{array}$ & \multicolumn{2}{|c|}{ Remaja akhir (17-25) } & 74 & 100,00 & 74 & 100,00 \\
\hline \multirow{5}{*}{$\begin{array}{c}\mathrm{IMT} \\
\left(\mathrm{kg} / \mathrm{m}^{2}\right)\end{array}$} & Kurus & $<18,5$ & & & 12 & 16,22 \\
\hline & Normal & $18,5-22,9$ & & & 42 & 56,75 \\
\hline & $\begin{array}{l}\text { Berisiko } \\
\text { obesitas }\end{array}$ & $23,0-24,9$ & & & \multirow[t]{3}{*}{20} & \multirow[t]{3}{*}{27,03} \\
\hline & Obesitas I & $25,0-29,9$ & 43 & 58,11 & & \\
\hline & Obesitas II & $\geq 30,0$ & 31 & 41,89 & & \\
\hline
\end{tabular}

IMT: Indeks Massa Tubuh

\section{Profil Pengetahuan Vitamin D}

Sebagian besar responden, baik dari kelompok obesitas dan nonobesitas memiliki tingkat pengetahuan mengenai vitamin D yang baik (Tabel 3). Hasil uji odss ratio pengetahuan mengenai vitamin D pada responden obesitas dan non-obesitas diperoleh nilai sebesar 1,138 . Nilai odds ratio tersebut berarti responden nonobesitas memiliki kecenderungan untuk memiliki pengetahuan baik adalah sebesar 1,138 sehingga dapat simpulkan responden obesitas dan non-obesitas sama-sama memiliki pengetahuan baik mengenai vitamin D. Hasil uji chi square diperoleh nilai Asymp Sig-nya 0,719 (>0,05) berarti tidak ada perbedaan yang signifikan pengetahuan mengenai vitamin $\mathrm{D}$ pada responden obesitas dan nonobesitas.

Tabel 2. Profil jawaban pengetahuan mengenai vitamin D pada kelompok obesitas dan non-obesitas

\begin{tabular}{|c|c|c|c|c|c|c|}
\hline \multirow{3}{*}{ No } & \multirow{3}{*}{ Pertanyaan } & \multirow{3}{*}{ Jawaban } & \multicolumn{4}{|c|}{ Kelompok } \\
\hline & & & \multicolumn{2}{|c|}{ Obesitas } & \multicolumn{2}{|c|}{ Non-Obesitas } \\
\hline & & & $\begin{array}{c}\text { Frekuensi } \\
(n: 74)\end{array}$ & $\begin{array}{c}\text { Persentase } \\
(100 \%)\end{array}$ & $\begin{array}{c}\text { Frekuensi } \\
(n: 74)\end{array}$ & $\begin{array}{c}\text { Persentase } \\
(100 \%)\end{array}$ \\
\hline 1 & Mengetahui tentang & $\mathrm{Ya}$ & 51 & 68,92 & 56 & 75,68 \\
\hline & vitamin D & Tidak & 23 & 31,08 & 18 & 24,32 \\
\hline 2 & & $\begin{array}{l}\text { Vitamin untuk } \\
\text { kesehatan tulang }\end{array}$ & 34 & 45,95 & 33 & 44,95 \\
\hline
\end{tabular}


Jurnal Ilmiah Ibnu Sina, 5(1), Maret 2020, 72-86

p-ISSN: 2502-647X; e-ISSN: 2503-1902

\begin{tabular}{|c|c|c|c|c|c|c|}
\hline \multirow{3}{*}{ No } & \multirow{3}{*}{ Pertanyaan } & \multirow{3}{*}{ Jawaban } & \multicolumn{4}{|c|}{ Kelompok } \\
\hline & & & \multicolumn{2}{|c|}{ Obesitas } & \multicolumn{2}{|c|}{$\begin{array}{l}\text { Non-Obesitas } \\
\end{array}$} \\
\hline & & & $\begin{array}{c}\text { Frekuensi } \\
(\mathrm{n}: 74)\end{array}$ & $\begin{array}{c}\text { Persentase } \\
(\mathbf{1 0 0 \%})\end{array}$ & $\begin{array}{l}\text { Frekuensi } \\
\text { (n:74) }\end{array}$ & $\begin{array}{c}\text { Persentase } \\
(100 \%)\end{array}$ \\
\hline & $\begin{array}{l}\text { Bila ya, yang } \\
\text { diketahui mengenai }\end{array}$ & $\begin{array}{l}\text { Vitamin untuk tulang } \\
\text { dan gigi }\end{array}$ & 3 & 4,05 & 4 & 5,41 \\
\hline & $\begin{array}{l}\text { vitamin } \mathrm{D} \\
\text { (3 jawaban terbanyak) }\end{array}$ & $\begin{array}{l}\text { Vitamin yang baik } \\
\text { untuk kesehatan kulit }\end{array}$ & 5 & 6,76 & 4 & 5,41 \\
\hline \multirow[t]{3}{*}{2} & $\begin{array}{l}\text { Sumber informasi } \\
\text { mengenai vitamin } \mathrm{D}^{*} \\
\text { (3 jawaban terbanyak) }\end{array}$ & $\begin{array}{l}\text { Apoteker/perawat/dokte } \\
\text { r/tenaga kesehatan } \\
\text { lainnya }\end{array}$ & 13 & 17,57 & 18 & 24,32 \\
\hline & & Buku & 34 & 45,95 & 36 & 48,65 \\
\hline & & Sekolah & 41 & 55,41 & 45 & 60,81 \\
\hline \multirow[t]{3}{*}{3} & Sumber terbesar & Matahari & 39 & 52,70 & 52 & 70,27 \\
\hline & vitamin $\mathrm{D}$ adalah & Vitamin atau suplemen & 19 & 25,68 & 16 & 21,62 \\
\hline & (4 jawaban terbanyak) & Sayur & 13 & 15,57 & 9 & 12,16 \\
\hline \multirow[t]{3}{*}{4} & Manfaat vitamin D & Untuk kesehatan kulit & 8 & 10,81 & 7 & 9,46 \\
\hline & bagi tubuh* & Untuk kesehatan tulang & 45 & 60,81 & 48 & 64,86 \\
\hline & (3 jawaban terbanyak) & Untuk kesehatan gigi & 5 & 6,76 & 7 & 9,46 \\
\hline \multirow[t]{3}{*}{5} & Akibat dari & Kanker & 14 & 18,92 & 18 & 24,32 \\
\hline & kekurangan vitamin D & Kegemukan & 9 & 12,16 & 2 & 2,70 \\
\hline & (3 jawaban terbanyak) & Penyakit tulang & 62 & 83,78 & 55 & 74,32 \\
\hline \multirow[t]{3}{*}{6} & $\begin{array}{l}\text { Penyebab tubuh } \\
\text { kekurangan vitamin D }\end{array}$ & $\begin{array}{l}\text { Menggunakan payung } \\
\text { pada siang hari }\end{array}$ & 20 & 27,03 & 12 & 16,22 \\
\hline & (3 jawaban terbanyak) & $\begin{array}{l}\text { Menggunakan pakai } \\
\text { tertutup }\end{array}$ & 23 & 31,08 & 35 & 47,30 \\
\hline & & $\begin{array}{l}\text { Menggunakan tabir } \\
\text { surya }\end{array}$ & 19 & 25,68 & 22 & 29,73 \\
\hline \multirow[t]{6}{*}{7} & Sinar matahari dapat & Ya & 40 & 54,05 & 33 & 44,59 \\
\hline & membantu & Tidak & 3 & 4,05 & 2 & 2,70 \\
\hline & $\begin{array}{l}\text { menghasilkan vitamin } \\
\text { D }\end{array}$ & Tidak tahu & 31 & 41,89 & 39 & 52,70 \\
\hline & $\begin{array}{l}\text { Bila ya, alasannya: } \\
\text { (3 jawaban terbanyak) }\end{array}$ & $\begin{array}{l}\text { Sinar matahari dapat } \\
\text { mengaktifkan vitamin } \\
\text { D }\end{array}$ & 5 & 6,76 & 2 & 2,70 \\
\hline & & $\begin{array}{l}\text { Mengubah provitamin } \\
\text { D menjadi vitamin D }\end{array}$ & 11 & 14,86 & 5 & 6,76 \\
\hline & & $\begin{array}{l}\text { Sinar matahari baik } \\
\text { untuk kesehatan tulang }\end{array}$ & 4 & 5,41 & 10 & 13,51 \\
\hline \multirow[t]{10}{*}{8} & Sinar matahari & Ya & 59 & 79,73 & 56 & 75,68 \\
\hline & berbahaya bagi kulit & Tidak & 8 & 10,81 & 9 & 12,16 \\
\hline & & Tergantung & - & - & 1 & 1,35 \\
\hline & & Tidak tahu & 7 & 9,46 & 6 & 8,11 \\
\hline & Bila ya, alasannya: & Terpapar siang hari & 12 & 16,22 & 19 & 25,68 \\
\hline & & $\begin{array}{l}\text { Terpapar terlalu lama } \\
\text { dan terlalu sering }\end{array}$ & 19 & 25,68 & 15 & 20,27 \\
\hline & & Sinar UV dari matahari & 17 & 22,97 & 11 & 14,86 \\
\hline & Bila tidak, alasannya: & $\begin{array}{l}\text { Sinar matahari memiliki } \\
\text { manfaat }\end{array}$ & - & - & 9 & 12,96 \\
\hline & & $\begin{array}{l}\text { Sinar matahari aman } \\
\text { dan memiliki manfaat }\end{array}$ & 8 & 10,81 & - & - \\
\hline & $\begin{array}{l}\text { Tergantung, } \\
\text { alasannya: }\end{array}$ & Tergantung jenis kulit & - & - & 1 & 1,35 \\
\hline \multirow[t]{2}{*}{9} & Waktu yang baik & $05.00 \mathrm{WIB}$ & 8 & 10,81 & 6 & 8,11 \\
\hline & untuk terkena paparan & $06.00 \mathrm{WIB}$ & 35 & 47,30 & 32 & 43,24 \\
\hline
\end{tabular}


Jurnal Ilmiah Ibnu Sina, 5(1), Maret 2020, 72-86

p-ISSN: 2502-647X; e-ISSN: 2503-1902

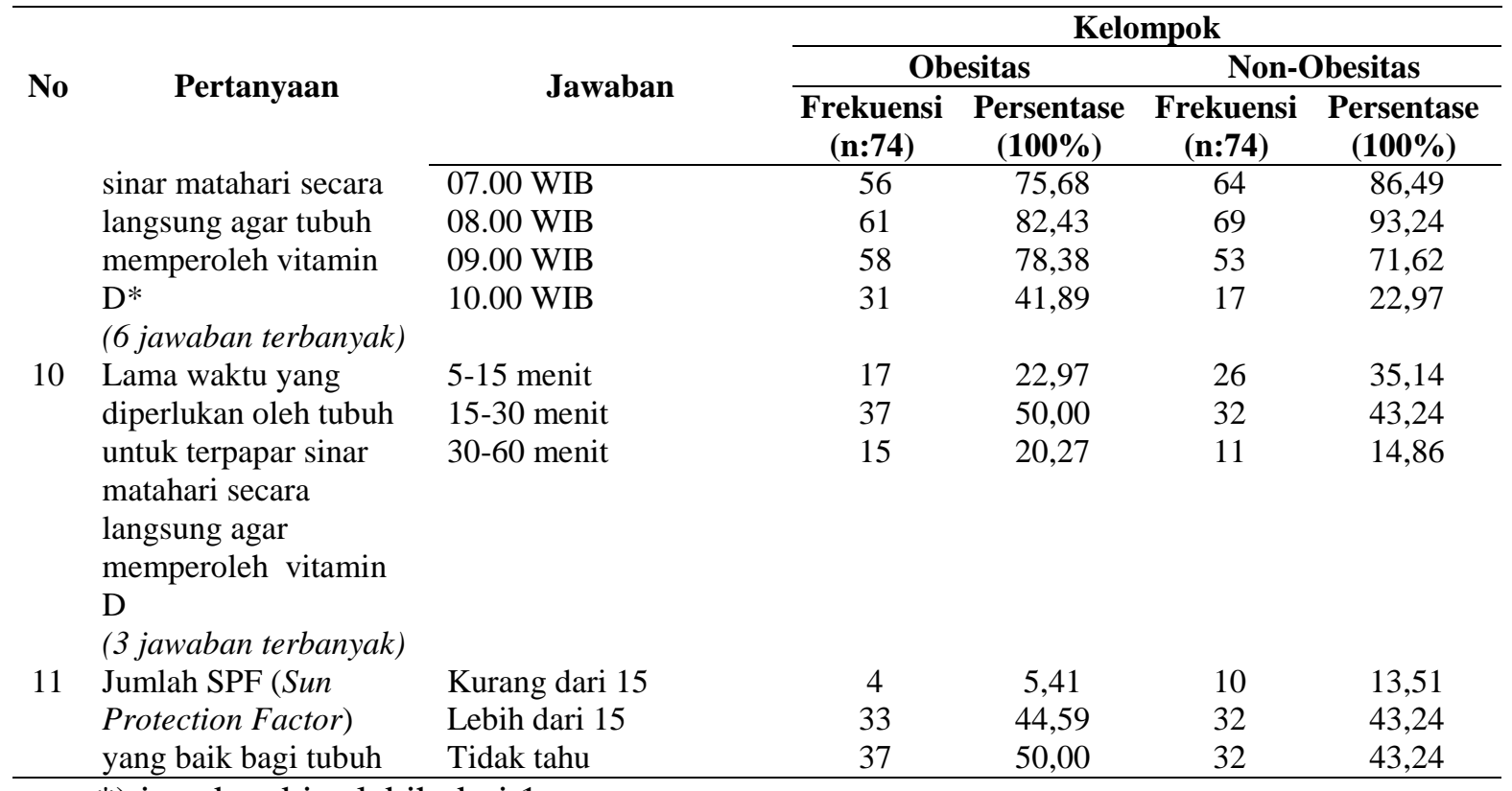

*) jawaban bisa lebih dari 1

Tabel 3. Tabulasi silang pengetahuan mengenai vitamin D pada kelompok obesitas dan non-obesitas

\begin{tabular}{ccccccc}
\hline \multirow{2}{*}{$\begin{array}{c}\text { Pengetahuan mengenai Vitamin } \\
\text { D }\end{array}$} & \multicolumn{4}{c}{ Kelompok } & \multirow{2}{*}{ Total } \\
\cline { 3 - 6 } $\begin{array}{c}\text { Jumlah } \\
\begin{array}{c}\text { Pertanyaan } \\
\text { Benar }\end{array}\end{array}$ & $\begin{array}{c}\text { Kategori } \\
\text { Pengetahuan }\end{array}$ & $\begin{array}{c}\text { Frekuensi } \\
(\mathbf{n : 7 4 )}\end{array}$ & $\begin{array}{c}\text { Persentase } \\
\mathbf{( 1 0 0 \% )}\end{array}$ & $\begin{array}{c}\text { Frekuensi } \\
(: \mathbf{7 4})\end{array}$ & $\begin{array}{c}\text { Persentase } \\
(\mathbf{1 0 0 \% )}\end{array}$ \\
\hline 66 & Baik & 51 & 68,92 & 53 & 71,62 & 104 \\
$<6$ & Buruk & 23 & 31,08 & 21 & 28,38 & 44 \\
& TOTAL & 74 & 100,00 & 74 & 100,00 & 148 \\
\hline
\end{tabular}

\section{Profil Sikap mengenai Vitamin D}

Walaupun sebagian besar responden memiliki tingkat pengetahuan yang baik, namun, sebagian besar responden baik obesitas dan non-obesitas justru memiliki tingkat sikap terhadap paparan sinar matahari yang buruk (Tabel 5). Hasil uji odss ratio sikap mengenai vitamin D pada responden obesitas dan non-obesitas diperoleh nilai sebesar 1,000. Nilai odds ratio tersebut berarti responden nonobesitas memiliki kecenderungan untuk memiliki sikap baik sebesar 1,000 sehingga dapat disimpulkan responden obesitas dan non-obesitas sama-sama memiliki sikap buruk mengenai vitamin D. Hasil uji chi square diperoleh nilai Asymp. Sig-nya $1,000(>0,05)$ berarti tidak ada perbedaan yang signifikan sikap mengenai vitamin D pada responden obesitas dan non-obesitas. 
Jurnal Ilmiah Ibnu Sina, 5(1), Maret 2020, 72-86

p-ISSN: 2502-647X; e-ISSN: 2503-1902

Tabel 4. Profil jawaban sikap mengenai vitamin D pada kelompok obesitas dan non-obesitas

\begin{tabular}{|c|c|c|c|c|c|c|}
\hline \multirow{4}{*}{ No } & \multirow{4}{*}{ Pertanyaan } & \multirow{4}{*}{ Jawaban } & \multicolumn{4}{|c|}{ Kelompok } \\
\hline & & & \multicolumn{2}{|c|}{ Obesitas } & \multicolumn{2}{|c|}{ Non-Obesitas } \\
\hline & & & \multicolumn{4}{|c|}{ Frekuensi Persentase FrekuensiPersentase } \\
\hline & & & (n:74) & $(100 \%)$ & $(n: 74)$ & $(\mathbf{1 0 0 \%})$ \\
\hline \multirow[t]{2}{*}{1} & Sering berpergian & $\mathrm{Ya}$ & 58 & 78,38 & 52 & 70,27 \\
\hline & $\begin{array}{l}\text { bawah sinar matahari } \\
\text { secara langsung }\end{array}$ & Tidak & 16 & 21,62 & 22 & 29.73 \\
\hline \multirow[t]{3}{*}{2} & Lama terpapar sinar & 5-10 menit/hari & 20 & 27,03 & 20 & 27,03 \\
\hline & matahari secara & 10-15 menit/hari & 20 & 27,03 & 24 & 32,43 \\
\hline & $\begin{array}{l}\text { (3 jawaban } \\
\text { terbanyak) }\end{array}$ & 15-30 menit/hari & 32 & 43,24 & 26 & 35,14 \\
\hline \multirow[t]{5}{*}{3} & Menghindari paparan & Ya & 56 & 75,63 & 58 & 78,38 \\
\hline & $\begin{array}{l}\text { sinar matahari secara } \\
\text { langsung }\end{array}$ & Tidak & 18 & 24,32 & 16 & 21,62 \\
\hline & $\begin{array}{l}\text { Bila ya, alasannya: } \\
\text { (3 jawaban }\end{array}$ & $\begin{array}{l}\text { Menimbulkan masalah } \\
\text { pada kulit }\end{array}$ & 11 & 14,86 & 8 & 10,81 \\
\hline & terbanyak) & $\begin{array}{l}\text { Panas dari sinar matahari } \\
\text { (UV) }\end{array}$ & 14 & 18,92 & 10 & 13,51 \\
\hline & & $\begin{array}{l}\text { Menyebabkan kulit } \\
\text { hitam/gelap }\end{array}$ & 19 & 25,68 & 25 & 33,78 \\
\hline \multirow[t]{6}{*}{4} & Menggunakan alat & $\mathrm{Ya}$ & 68 & 91,89 & 70 & 94,59 \\
\hline & $\begin{array}{l}\text { paparan sinar } \\
\text { matahari secara } \\
\text { langsung }\end{array}$ & Tidak & 6 & 8,11 & 4 & 5,41 \\
\hline & *Alat pelindung yang & Payung & 8 & 10,81 & 8 & 10,81 \\
\hline & digunakan: & Topi & 8 & 10,81 & 7 & 9,46 \\
\hline & & Jaket & 59 & 79,73 & 56 & 75,68 \\
\hline & & Tabir surya & 27 & 36,49 & 31 & 41,89 \\
\hline \multirow[t]{3}{*}{5} & $\begin{array}{l}\text { Alasan menggunakan } \\
\text { alat pelindung }\end{array}$ & $\begin{array}{l}\text { Mudah digunakan, mudah } \\
\text { didapat dan efektif }\end{array}$ & 25 & 33,78 & 20 & 27,03 \\
\hline & $\begin{array}{l}\text { (3 jawaban } \\
\text { terbanyak) }\end{array}$ & $\begin{array}{l}\text { Melindungi kulit dari } \\
\text { panas sinar matahari (UV) }\end{array}$ & 18 & 24,32 & 23 & 31,08 \\
\hline & & $\begin{array}{l}\text { Melindungi kulit agar } \\
\text { tidak gelap (gosong) }\end{array}$ & 15 & 20,27 & 7 & 9,46 \\
\hline \multirow[t]{3}{*}{6} & $\begin{array}{l}\text { Mengkonsumsi } \\
\text { suplemen }\end{array}$ & $\begin{array}{l}\text { Ya (mengandung vitamin } \\
\text { D) }\end{array}$ & 1 & 1,35 & 3 & 4,05 \\
\hline & & $\begin{array}{l}\text { Ya (tidak mengandung } \\
\text { vitamin D) }\end{array}$ & 18 & 24,32 & 13 & 17,57 \\
\hline & & Tidak & 55 & 74,32 & 58 & 78,38 \\
\hline \multirow[t]{3}{*}{7} & $\begin{array}{l}\text { Bila ya (mengandung } \\
\text { vitamin } D),\end{array}$ & $\begin{array}{l}\text { Menjaga kesehatan dan } \\
\text { kebugaran }\end{array}$ & - & - & 1 & 1,35 \\
\hline & alasannya: & Menjaga kesehatan & 1 & 1,35 & 1 & 1,35 \\
\hline & & Menjaga sistem imun & - & - & 1 & 1,35 \\
\hline \multirow[t]{6}{*}{8} & Kebutuhan vitamin D & $\mathrm{Ya}$ & 39 & 52,70 & 33 & 44,59 \\
\hline & dalam tubuh sudah & Tidak & 10 & 13,51 & 19 & 25,68 \\
\hline & mencukupi & Tidak tahu & 25 & 33,78 & 22 & 29,73 \\
\hline & Bila ya, alasannya: & $\begin{array}{l}\text { Sering terpapar sinar } \\
\text { matahari }\end{array}$ & 8 & 10,81 & 8 & 10,81 \\
\hline & & Pola hidup sehat & 18 & 24,32 & 12 & 16,22 \\
\hline & & Merasa sehat & 13 & 17,57 & 13 & - \\
\hline
\end{tabular}


Jurnal Ilmiah Ibnu Sina, 5(1), Maret 2020, 72-86

p-ISSN: 2502-647X; e-ISSN: 2503-1902

\begin{tabular}{|c|c|c|c|c|c|c|}
\hline \multirow{3}{*}{ No } & \multirow{3}{*}{ Pertanyaan } & \multirow{3}{*}{ Jawaban } & \multicolumn{4}{|c|}{ Kelompok } \\
\hline & & & Obc & sitas & Non- & \\
\hline & & & $\begin{array}{l}\text { Frekuensi } \\
\text { (n:74) }\end{array}$ & $\begin{array}{l}\text { Persentase } \\
(\mathbf{1 0 0 \%})\end{array}$ & $\begin{array}{l}\text { Frekuens } \\
\text { (n:74) }\end{array}$ & $\begin{array}{l}\text { Persentase } \\
(\mathbf{1 0 0 \%})\end{array}$ \\
\hline \multirow{8}{*}{9} & \multirow[t]{2}{*}{ Bila tidak, alasannya: } & Pola hidup tidak sehat & 10 & 31,51 & 14 & 18.92 \\
\hline & & $\begin{array}{l}\text { Merasa kebutuhhan } \\
\text { vitamin D masih kurang }\end{array}$ & - & - & 5 & 6,76 \\
\hline & $\begin{array}{l}\text { Tertarik untuk } \\
\text { mengetahui lebih }\end{array}$ & $\mathrm{Ya}$ & 58 & 78,38 & 54 & 72,97 \\
\hline & $\begin{array}{l}\text { banyak tentang vitamin } \\
\text { D }\end{array}$ & Tidak & 16 & 21,62 & 20 & 27,03 \\
\hline & Bila ya, alasannya: & Untuk kesehatan & 14 & 18.92 & 19 & 25,68 \\
\hline & (3 jawaban & Menambah pengetahuan & 34 & 45.95 & 31 & 41,89 \\
\hline & terbanyak) & Sekedar ingin tahu & 6 & 8,11 & 2 & 2,70 \\
\hline & Bila tidak, alasannya: & $\begin{array}{l}\text { Tidak ingin mengetahui } \\
\text { tentang vitamin D }\end{array}$ & 16 & 21,62 & 20 & 27,03 \\
\hline
\end{tabular}

Tabel 5. Tabulasi silang sikap mengenai vitamin D pada kelompok obesitas dan non-obesitas

\begin{tabular}{|c|c|c|c|c|c|c|}
\hline \multirow{2}{*}{\multicolumn{2}{|c|}{ Sikap mengenai Vitamin D }} & \multicolumn{4}{|c|}{ Kelompok } & \multirow{3}{*}{ TOTAL } \\
\hline & & \multicolumn{2}{|c|}{ Obesitas } & \multicolumn{2}{|c|}{ Non-Obesitas } & \\
\hline $\begin{array}{c}\text { Skor } \\
\text { Pertanyaan }\end{array}$ & Kategori Sikap & $\begin{array}{c}\text { Frekuensi } \\
\text { (n:74) }\end{array}$ & $\begin{array}{c}\text { Persentase } \\
(\%)\end{array}$ & $\begin{array}{c}\text { Frekuensi } \\
\text { (n:74) }\end{array}$ & $\begin{array}{l}\text { Persentase } \\
(\%)\end{array}$ & \\
\hline$<10$ & Baik & 4 & 5,41 & 4 & 5,41 & 8 \\
\hline$\geq 10$ & Buruk & 70 & 94,59 & 70 & 94,59 & 140 \\
\hline \multicolumn{2}{|c|}{ TOTAL } & 74 & 100,00 & 74 & 100,00 & 100,00 \\
\hline
\end{tabular}

\section{Uji Korelasi Pengetahuan dan Sikap}

\section{mengenai Vitamin D}

Hasil uji korelasi pengetahuan dan sikap mengenai vitamin D pada responden obesitas dan non-obesitas ialah 0,041 . Nilai uji korelasi 0,041 atau masuk dalam rentang $>0$ sampai 0,25 artinya kedua variabel yaitu pengetahuan dan sikap mengenai vitamin D memiliki korelasi yang sangat lemah.

Profil jawaban responden aspek pengetahuan (Tabel 2) dan sikap (Tabel 4) responden mengenai vitamin D berdasarkan adalah sebagai berikut:

\section{Informasi mengenai vitamin $D$}

Responden obesitas mengetahui informasi mengenai vitamin D paling banyak lewat buku $(45,95 \%)$ dan responden nonobesitas paling banyak mengetahui tentang vitamin D dari sekolah $(60,81 \%)$. Indonesia kaya akan sinar matahari yang merupakan sumber terbesar dari vitamin $\mathrm{D}$, tetapi sudah mulai muncul risiko defisiensi vitamin D (Ernawati dan Budiman, 2015; Suryadinata et al., 2017). 


\section{Sumber vitamin D}

Responden non-obesitas memiliki pengetahuan yang lebih baik tentang sumber terbesar dari vitamin D, yaitu berasal dari sinar matahari (Muhairi et al., 2013; Al-Mogbel, 2012; Nair dan Arun, 2012). Sinar matahari mengandung sinar ultraviolet $\mathrm{B}$ (UVB) yang dapat mengubah 7dehidrokolesterol (pro vitamin D3) di kulit menjadi kolekalsiferol (vitamin D3) (Sunita, 2010).

\section{Manfaat vitamin D}

Responden obesitas yang menjawab vitamin $\mathrm{D}$ baik baik untuk kesehatan tulang 60,81\% sedangkan responden nonobesitas $64,86 \%$. Vitamin D dapat membantu pembentukan dan pemeliharaan tulang serta bisa membantu pengerasan tulang dengan cara mengatur agar kalsium dan fosfor tersedia di dalam darah untuk diendapkan dalam proses pengerasan tulang (Sunita, 2010).

\section{Akibat kekurangan vitamin D}

Responden obesitas menjawab $18,92 \%$ untuk kanker, $12,16 \%$ untuk kegemukan, penyakit kolesterol 2,70\% penyakit tulang $83,78 \%$ dan tekanan darah tinggi 6,76\%. Penyebab tubuh kekurangan vitamin $\mathrm{D}$ terkait paparan sinar matahari adalah menggunakan payung, pakaian tertutup, dan tabir surya pada siang hari (Qureshi et al., 2015; American Skin Association, 2012), dapat menghambat pembentukan pembentukan vitamin D di kulit oleh sinar ultraviolet yang berasal dari matahari (Sunita, 2010). Sinar matahari sebagai sumber vitamin D

Sinar matahari yang baik bagi tubuh karena dapat membentu vitamin D di kulit ialah sinar matahari yang dari jam 10.0014.00 WIB, dengan durasi yang sesuai dengan warna kulit. Lama paparan tergantung dari tipe kulit. Semakin kulit memiliki pigmen maka semakin lama sintesis vitamin D di kulit. Asia cenderung memiliki tipe kulit III sampai V (Pengpid dan Peltzer, 2015). Semakin gelap warna kulit, semakin besar jumlah melanin 
Jurnal Ilmiah Ibnu Sina, 5(1), Maret 2020, 72-86

p-ISSN: 2502-647X; e-ISSN: 2503-1902

pada epidermis kulit. Melanin dapat bersaing dengan 7dehidrokolesterol untuk penyerapan UVB, sehingga orang dengan kulit berwarna gelap, kurang efisien untuk memproduksi vitamin D di kulit, atau membutuhkan waktu yang lebih lama jika dibandingan dengan orang yang memiliki tipe kulit I atau II (Zang dan Naughthon, 2010). IMT bisa mempengaruhi lama paparan terhadap sinar matahari, karena orang dengan IMT yang tinggi, bisa menyebabkan ketersediaan vitamin D dalam darah menurun karena orang dengan IMT yang tinggi memiliki lemak tubuh yang lebih tinggi dibandingkan dengan yang memiliki IMT rendah (Vaquez et al, 2014).

\section{Pelindung dari paparan sinar} matahari

Responden obesitas yang menggunakan tabir surya dengan SPF $<15$ yaitu $5,41 \%$ sedangkan pada responden non-obesitas 13,51\%. Tabir surya dengan SPF 8 mengurangi produksi previtamin D3 sebesar 95\% dan
SPF 15 sebesar 99\% (Zang dan Naughthon, 2010). sedangkan American Skin Association (2012) menyarankan tabir surya yang baik bagi tubuh untuk mencegah kanker kulit ialah tabir surya yang mengandung $\mathrm{SPF} \geq 15$.

\section{Uji Odds Ratio dan Chi-square}

Uji odss ratio pengetahuan mengenai vitamin $\mathrm{D}$ pada responden obesitas dan non-obesitas diperoleh nilai sebesar 1,138 yang berarti responden non-obesitas kecenderungan memiliki pengetahuan baik sebesar 1,138 sehingga dapat simpulkan responden obesitas dan non-obesitas sama-sama memiliki pengetahuan baik mengenai vitamin D. Selanjutnya penilaian ada tidaknya perbedaan pengetahuan pada responden obesitas dan non-obesitas dilakukan dengan uji chi-square, yang menunjukkan nilai Asymp. Sig-nya $1,000(>0,05)$ berarti tidak ada perbedaan yang signifikan pengetahuan mengenai vitamin $\mathrm{D}$ pada responden obesitas dan nonobesitas.

Uji dengan chi-square menunjukkan tidak ada perbedaan yang signifikan pengetahuan pada 
Jurnal Ilmiah Ibnu Sina, 5(1), Maret 2020, 72-86

p-ISSN: 2502-647X; e-ISSN: 2503-1902

responden obesitas dan non-obesitas. Sehingga penelitian ini memiliki hasil yang berbeda dengan penelitian sebelumnya yang dilakukan oleh Valint (2013) untuk melihat risiko defisiensi vitamin D pada dewasa obesitas dan non-obesitas diketahui bahwa responden dewasa dengan obesitas memiliki risiko defisiensi vitamin D yang lebih besar dibanding dengan dewasa non-obesitas.

Sedangkan pada sikap, hasil uji odds ratio pada responden obesitas dan non-obesitas diperoleh nilai sebesar 1,000, berarti dapat disimpulkan bahwa responden obesitas dan nonobesitas sama-sama memiliki sikap buruk mengenai vitamin D. Melihat ada tidaknya perbedaan pengetahuan pada responden obesitas dan nonobesitas perlu dilakukan uji chi-square yang hasilnya tidak ada perbedaan sikap mengenai vitamin D pada responden obesitas dan non-obesitas.

\section{Uji Korelasi Pengetahuan Dan}

\section{Sikap mengenai Vitamin D}

Hasil uji korelasi pengetahuan dan sikap mengenai vitamin D pada responden obesitas dan non-obesitas ialah 0,041. Jika nilai uji korelasi 0,041 atau masuk dalam rentang >0 sampai 0,25 artinya kedua variabel (pengetahuan dan sikap terhadap paparan sinar matahari) memiliki korelasi yang sangat lemah.

Hasil uji korelasi pengetahuan dan sikap memiliki hubungan yang sangat lemah. Responden obesitas dan non-obesitas memiliki pengetahuan yang baik tentang vitamin $\mathrm{D}$ tetapi sama-sama memiliki sikap yang buruk. Pengetahuan mempengaruhi sikap. Sikap dapat ditumbu kembangkan melalui proses belajar, artinya sikap dapat dipengaruhi oleh pengetahuan sehingga apabila pengetahuan ditingkatkan maka sikap yang baik terhadap vitamin $\mathrm{D}$ juga akan meningkat (Qureshi et al., 2015). Pengetahuan responden penelitian tentang sumber, manfaat, dan penyebab defisiensi vitamin $D$ sudah baik, tetapi pengetahuan tentang waktu dan durasi yang tepat untuk tubuh dapat menghasilkan vitamin D dari matahari masih kurang, sehingga hal tersebut mempengaruhi sikap responden terhadap paparan sinar matahari. Responden cenderung menghindari paparan sinar matahari pada saat siang hari padahal pada saat 
Jurnal Ilmiah Ibnu Sina, 5(1), Maret 2020, 72-86

p-ISSN: 2502-647X; e-ISSN: 2503-1902

siang hari tubuh dapat menghasilkan vitamin D.

\section{KESIMPULAN}

Dari hasil penelitian diperoleh kesimpulan bahwa:

1. Responden obesitas dan nonobesitas sama-sama memiliki pengetahuan baik mengenai vitamin $\mathrm{D}$, namun kedua kelompok juga memiliki sikap buruk mengenai vitamin D.

2. Tidak ada perbedaan signifikan pengetahuan dan sikap mengenai vitamin D pada responden obesitas dan non-obesitas.

3. Pengetahuan dan sikap terhadap mengenai vitamin $\mathrm{D}$ pada dewasa obesitas dan non-obesitas memiliki korelasi sangat lemah.

\section{UCAPAN TERIMA KASIH}

Para peneliti mengucapkan terima kasih atas dukungan Hibah LPPM Universitas Surabaya.

\section{DAFTAR PUSTAKA}

Al-Mogbel, E.S. (2012) 'Vitamin D Status among Adults Saudi Females Visiting Primary Health Care Clinics', Int J Health Sci Qassim University, 6(2),pp.116-26.
American Skin Association. (2012) 'Sun Safety' (online), Available at: http://www.americanskin.org/r esource/safety.php [diakses 1 April 2018]

Arora, H., Dixit, V., Srivastava, N. (2016). 'Evaluation of Knowledge, Practice of Vitamin D and Attitide Toward Sunlight Among Indian Students', Asian Journal of Pharmaceutical Clinical Research, 9(1),pp.308-313.

Bolek-Berquist, J., Elliott, M.E., Gangnon, R.E., Gemar, D., Engelke, J., Lawrence, S.J., Hansen, K. (2009). 'Use of a Questionnaire to Assess Vitamin D Status in Young Adults', Public Health Nutrition, 12(2),pp.236-243.

Ernawati, F., Budiman, B. (2015). 'Status Vitamin D terkini Anak Indonesia', SEANUTS, 38(1),pp.73-80.

Fleury, N., Geldenhuys, S., Gorman, S. (2016). 'Sun Exposure and Its Effects on Human Health: Mechanisms through Which Sun Exposure Could Reduce the Risk of Developing Obesity and Cardiometabolic Dysfunction', Int J Environ Res Public Health, 13(10),pp.999.

Kung, A., Lee, K.K. (2006). 'Research article: Knowledge of vitamin $D$ and perceptions and attitudes toward sunlight among Chinese middle-age and elderly women: a population survey in Hong Kong', BMC Public Health, 7(6),pp.226. 
Jurnal Ilmiah Ibnu Sina, 5(1), Maret 2020, 72-86

p-ISSN: 2502-647X; e-ISSN: 2503-1902

Muhairi, S.J., Mehairi, A.E., Khouri, A.A., Naqbi, M.M., Maskari, F.A., Al-Kaabi, J., Al-Dhaheri, A.S., Nagelkerke, N., Shah, S.M. (2013). 'Vitamin Deficiency Among Healthy Adolescents in Al Ain, United Arab Emirates', BMC Public Health, 13(33),pp.1-7.

Nair, R., Arun, M. (2012). 'Vitamin D: The "Sunshine" Vitamin', J Pharmacol Pharmacother, 3(2),pp.118-126.

Nimitphong, H., Holick, M.F. (2013). 'Vitamin D status and sun exposure in Southeast Asia', Department of Medicine Dermato-Endocrinology, 5(1),pp.34-37.

Pengpid, S., Peltzer, K. (2015). 'Sun Protection Use Behaviour Among University Studens from 25 Low, Middle Income and Emerging Economy Countries', Asiean Pasific Journal of Cancer Prevention, 16(4),pp.1385-9.

Qureshi, A.Z., Zia, Z., Gitay, M.N., Khan, M.U., Khan, M.S. (2015). 'Attitude of future healthcare provider towords vitamin $D$ significance in relation to sunlight exposure', Saudi Pharmaceutical Journal, 23(5),pp.523-527.

Sunita, A. (2010). Prinsip Dasar Ilmu Gizi. Jakarta: Gramedia Pustaka Utama.p.167-173.

Suryadinata, R.V., Lorensia, A., Aprilia, A.P. (2017). 'Profil
Vitamin D pada Pasien Asma dan Non-Asma Dewasa di Surabaya', The Indonesian Journal of Public Health, 12(1),pp.106-117.

Vanlint, S. (2013). 'Vitamin D and Obesity'. Nutrien, 5(3),pp.949956.

Vimaleswaran, K.S., Berry, D.J., Lu, C., Tikkanen, E., Pilz, S., Hiraki, L.T., et al. (2013). 'Causal Relationship between Obesity and Vitamin D Status: Bi-Directional Mendelian Randomization Analysis of Multiple Cohorts', PLOS Medicine, 10 (2),pp.e1001383.

Walker, N., Thomas, D.L., Dane, F.B., Phillip, B.H., Jillian, H. Antony, S.E., Katherine, E.B. (2014). 'Knowledge and attitudes to vitamin $D$ and sun exposure in elite New Zealand athletes: a cross-sectional study', Journal of the international society of sports nutrition, 11(47),pp.1-6.

WHO. (2016) 'Obesity Adults' (Online) Available at: http://www.who.int/mediacent re/factsheets/fs311/en/ [diakses 1 April 2018]

Zhou, M., Zhuang, W., Yuan, Y., Li, Z., Cai, Y. (2016). 'Investigation on Vitamin D Knowledge, Attitude and Practice of University Students in Najing, China', Public Health Nutrition, 19(1),pp.7882. 


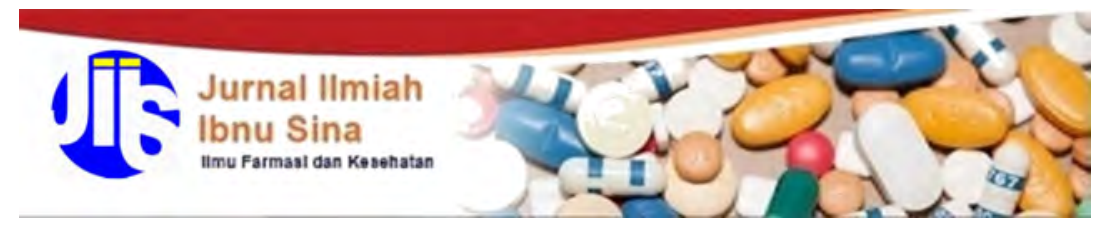

Archives Announcements Editorial Team Submissions About

\section{Search}

Home / Editorial Team

\section{REVIEWER}

Prof. Dr. Suwijiyo Pramono, DEA., Apt (Universitas Gadjah Mada)

Prof. Dr. Zullies Ikawati, Apt (Universitas Gadjah Mada)

Prof. Agung Endro Nugroho, M.Si.,Ph.D., Apt (Universitas Gadjah Mada)

Prof. Abdul Rohman, M.Si.,Ph.D.,_Apt (Universitas Gadjah Mada)

Prof. Dr. Dyah Aryani Perwitasari, M.Si.,Ph.D., Apt (Universitas Ahmad Dahlan)

Prof. Muchtaridi, M.Si.,Ph.D, Apt (Universitas Padjajaran, Indonesia)

Prof. Dr. Gemini Alam, M.Si.,_Apt. (Universitas Hasanuddin, Indonesia)

Dr. Brahmaputra Marjadi, MPH., Ph.D. (Western Sydney University)

Dr. AP. Moch Fadli Asmani (Management and Science University, Malaysia)

Dr. rer. nat. Endang Darmawan, Apt (Universitas Ahmad Dahlan)

\section{EDITOR}

Siska Musiam, S.Si.,_M.Si. (Akademi Farmasi ISFI Banjarmasin)

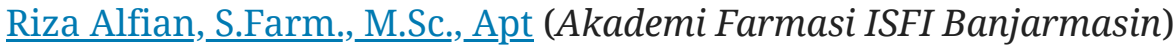




\section{Dwi Rizki Febrianti, M.Farm.,Apt (Akademi Farmasi ISFI Banjarmasin)}

Rakhmadhan Niah, M.Farm., Apt (Akademi Farmasi ISFI Banjarmasin)

Eka Kumalasari, M.Farm., Apt (Akademi Farmasi ISFI Banjarmasin)

\section{ACCREDITATION}

\section{SERTIFTKAT}

Direktorat Jenderal Penguatan Riset dan Pengembangan,

Kementerian Riset, Teknologi, dan Pendidikan Tinggi

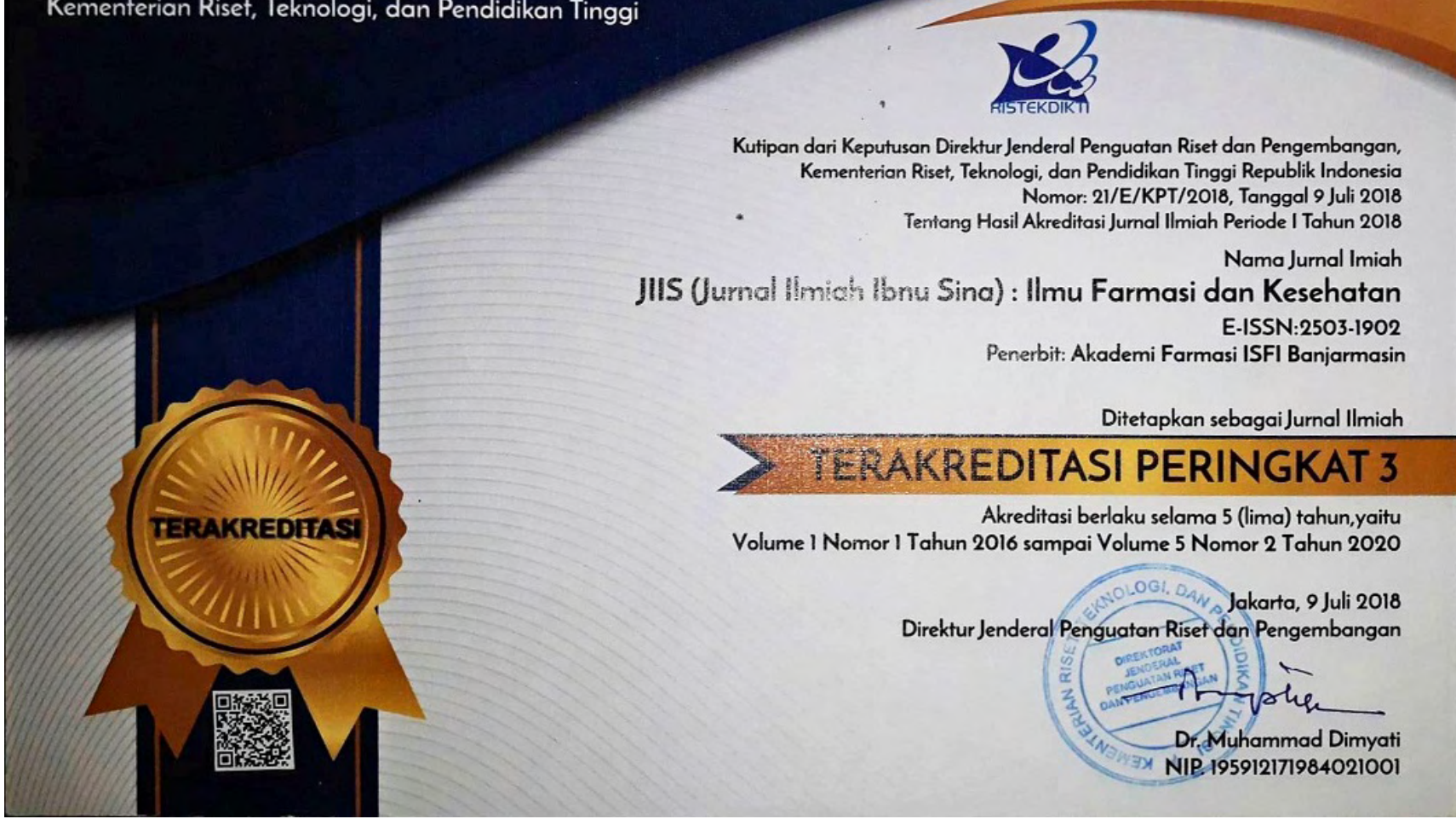

\section{VISITOR}

\section{Visitors}

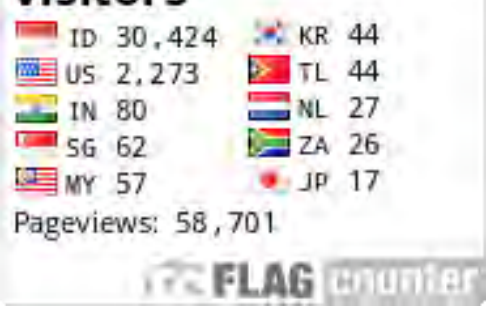

View My Stats 


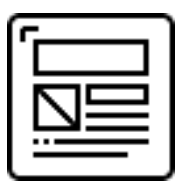

TOOLS

Plagiarism

$$
\text { Checker }
$$
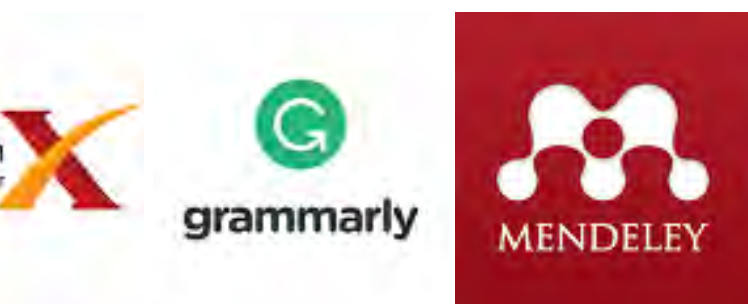

INDEXED BY:

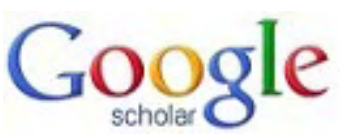

BASE

Ondonosid Search

Csînta

C) GARUDA

\section{Crossref}

p-ISSN: 2502-647X; e-ISSN: 2503-1902 


\section{Redaksi Jurnal Ilmiah Ibnu Sina}

Akademi Farmasi ISFI Banjarmasin

Jl. Flamboyan III/7b Kayu Tangi 70123

Banjarmasin Kalimantan Selatan

Telepon: (0511)-3301610, 3300221

Email: jiis@akfar-isfibjm.ac.id

\section{Platform \& workflow by OJS / PKP}




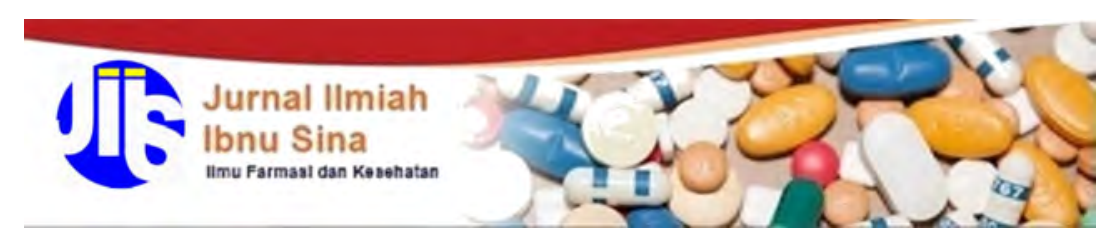

Archives Announcements Editorial Team Submissions About

Search

\section{Author Fees}

2020-02-19

Mulai terbitan Volume 5 Nomor 1 Maret 2020, Jurnal Ilmiah Ibnu Sina menetapkan Article Processing Charges (APCs) untuk setiap artikel yang diterbitkan sebesar Rp500.000,00. Tagihan pembayaran dilakukan bersamaan dengan pengiriman Letter of Acceptance (LoA) setelah artikel melewati proses peer-reviewed dan siap diterbitkan. Read More >

\section{Author Fees}

柴 2019-08-06

JIIS Vol. 3 No. 2 Oktober 2018

2018-08-06

JIIS Vol. 2 No. 1 Maret 2017

2017-02-01

\section{Current Issue}

Vol 5 No 1 (2020) 


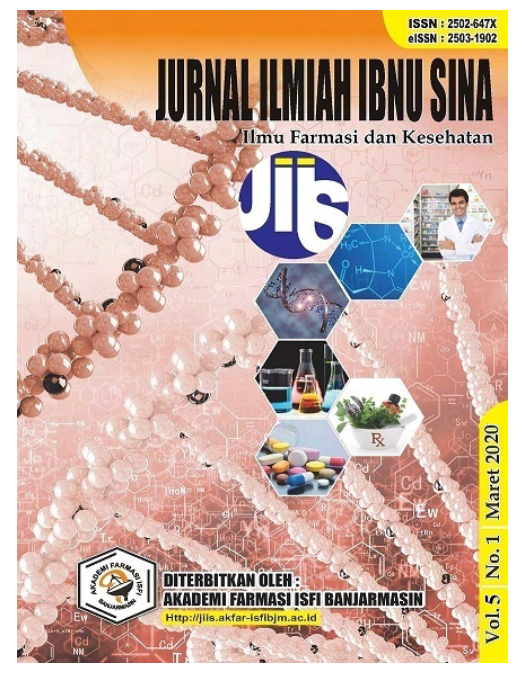

Published: 2020-03-30

\section{Artikel}

KARAKTERISASI SIMPLISIA DAN EKSTRAK DAUN BANDOTAN (Ageratum conyzoides L) SEBAGAI KANDIDAT OBAT KARIES GIGI

Ika Ayu Mentari, Wirnawati Wirnawati, Maulina Rahmawati Putri

1-9

PDF (Bahasa Indonesia)

UJI AKTIVITAS ANTIBAKTERI SEDIAAN MIKROEMULSI MINYAK JINTEN HITAM (Nigella sativa L.) TERHADAP TIGA BAKTERI PENYEBAB JERAWAT

Sani Ega Priani, Tati Kurniati, Lanny Mulqie

10-19

ه PDF (Bahasa Indonesia)

PENGARUH PEMBERIAN KONSELING MENGGUNAKAN BOOKLET TERHADAP PENGETAHUAN DIABETES MELLITUS MASYARAKAT DI KECAMATAN ANGGANA, KALIMANTAN TIMUR

Deasy Nur Chairin Hanifa, Ika Ayu Mentari

20-26

因 PDF (Bahasa Indonesia)

MINYAK ATSIRI JERUK KALAMANSI (Citrus microcarpa) SEBAGAI FORMULASI MASKER GEL (Peel-Off Mask)

Yuska Noviyanty, Hepiyansori Hepiyansori, Fransisca Epri Esaliya

27-36

PDF (Bahasa Indonesia) 
UJI AKTIVITAS ANTIBAKTERI EKSTRAK METANOL DAUN JERUK PURUT (Citrus hystrix (D.C)) TERHADAP BAKTERI Propionibacterium acnes

Fitriyanti Fitriyanti, Muhammad Hafizudin, Muhammad Nazarudin $37-43$

슷 (Bahasa Indonesia)

AKTIVITAS IMUNOMODULATOR EKSTRAK ETANOL SPONS Callyspongia sp. TERHADAP FAGOSITOSIS MAKROFAG PADA MENCIT JANTAN BALB/C.

Muhammad Ilyas Y., Asriullah Jabbar, Mentarri Bafadal, Muhammad Hajrul Malaka, Firdayanti Firdayanti, I. Sahidin

44-55

因 PDF (Bahasa Indonesia)

\section{ANALISIS MUTU PELAYANAN PETUGAS FARMASI DAN KETERSEDIAAN OBAT TERHADAP KEPUASAN PASIEN RAWAT JALAN DI RS SANTA CLARA MADIUN TAHUN 2019}

Diah Nurcahyani, Vidya Kartikaningrum

$56-63$

PDF (Bahasa Indonesia)

EFEK ADAPTOGENIK EKSTRAK ETANOL KULIT BUAH MANGGIS (Garcinia mangostana L.) PADA MENCIT (Mus musculus) MENGGUNAKAN METODE SWIMMING ENDURANCE TEST

Abdul Wahid Jamaluddin, A. Magfira Satya Apada

64-71

因 PDF (Bahasa Indonesia)

PENGARUH PENGETAHUAN-SIKAP MENGENAI VITAMIN D TERKAIT OBESITAS PADA MAHASISWA

Amelia Lorensia, Dian Natasya Raharjo, Novelia Gandawari $72-86$

因 PDF (Bahasa Indonesia)

STUDI PENGEMBANGAN INSTRUMEN EDUKASI UNTUK MENURUNKAN RISIKO PCOS (Polycystic Ovary Syndrome) PADA WANITA DENGAN OBESITAS

Ratna Widyasari, Adhisty Kharisma Justicia, Pinda Hutajulu $87-95$

PDF (Bahasa Indonesia)

PENGARUH ALARM MINUM OBAT (AMINO) UNTUK MENINGKATKAN KEPATUHAN MINUM OBAT PASIEN HIPERTENSI

Yusmaniar Yusmaniar, Yugo Susanto, Surahman Surahman, Riza Alfian

96-107 
内 PDF (Bahasa Indonesia)

\section{GAMBARAN TINGKAT KEPUASAN PASIEN BPJS RAWAT JALAN TERHADAP PELAYANAN} KEFARMASIAN DI INSTALASI FARMASI RSD IDAMAN BANJARBARU TAHUN 2019

Depy Oktapian Akbar, Gusti Dewi Handayani, Aristha Novyra Putri 108-116

$\triangle$ PDF (Bahasa Indonesia)

AKTIVITAS ANTIBAKTERI EKSTRAK DADANGKAK (Hydrolea spinosa) TERHADAP BAKTERI Bacillus subtilis, Staphylococcus aureus DAN Escherichia coli

Putri Vidiasari Darsono, M. Fajriannor T. M.

$117-127$

因 PDF (Bahasa Indonesia)

UJI AKTIVITAS EKSTRAK KENTAL ETANOL PANDAN HUTAN JENIS BARU (Freycinetia sessiliflora RIZKI) TERHADAP PERTUMBUHAN BAKTERI Staphylococcus aureus

Fitri Sri Rizki, Ade Ferdinan

128-136

속 PDF (Bahasa Indonesia)

VALIDASI METODE KROMATOGRAFI LAPIS TIPIS (KLT)-DENSITOMETRI UNTUK PENETAPAN KADAR $\beta$-KAROTEN DALAM TABLET KUNYAH EKSTRAK Spirulina platensis

Siti Fatmawati Fatimah, Citra Ariani Edityaningrum, Wihasty Nur Istyqomah, Ibnu Gholib Gandjar, Laela Hayu Nurani

$137-148$

因 PDF (Bahasa Indonesia)

UJI AKTIVITAS ANTIOKSIDAN EKSTRAK ETANOL DAUN DAN KULIT BATANG KALANGKALA (Litsea angulata) ASAL KALIMANTAN SELATAN

Eka Fitri Susiani, Revita Saputri 149-155

园 PDF (Bahasa Indonesia)

STUDI EFEKTIVITAS REDUKSI KADAR FORMALIN PADA TAHU DENGAN PERENDAMAN AIR KUNYIT, AIR CUKA DAN AIR GARAM DALAM UPAYA PENYEDIAAN PANGAN AMAN

Kadek Duwi Cahyadi, Agustina Nila Yuliawati, Gusti Ayu Dewi Lestari 156-164

因 PDF (Bahasa Indonesia) 
BIAYA MEDIK LANGSUNG PASIEN STROKE NON-HEMORAGIK KELAS PERAWATAN 3 RSUD K.R.M.T WONGSONEGORO SEMARANG

Hanik Utaminingrum, Fef Rukminingsih

$165-170$

国 PDF (Bahasa Indonesia)

PENENTUAN KADAR FENOLIK TOTAL EKSTRAK ETANOL 96\% DAUN TERAP (Artocarpus odoratissimus Blanco) DENGAN METODE SPEKTROFOTOMETRI VISIBEL

Anna Khumaira Sari, Noor Aisyah, Ahmad Sejali

$171-179$

PDF (Bahasa Indonesia)

FORMULASI EKSTRAK ETANOL DAGING BUAH PEPAYA (Carica papaya LINN) DALAM BASIS LOTION, UJI SIFAT FISIK DAN NILAI SPFNYA

Febrianika Ayu Kusumaningtyas, Iis Wahyuningsih, Nining Sugihartini

$180-190$

소 PDF (Bahasa Indonesia)

PENGARUH EKSTRAK AIR KULIT BUAH PISANG AMBON (Musa paradisiaca L.) PADA MODEL HEWAN RESISTENSI INSULIN

Elis Susilawati, Nita Selifiana, Sinta Paramudita Supriana

$191-200$

因 PDF (Bahasa Indonesia)

KARAKTERISTIK PROTEIN IKAN SEPAT RAWA (Trichopodus thricopterus) ASAL KALIMANTAN SELATAN YANG BERPOTENSI SEBAGAI ANTIDIABETES

Karunita Ika Astuti, Fitriyanti Fitriyanti

201-210

PDF (Bahasa Indonesia)

View All Issues >

\section{KEBIJAKAN EDITOR:}

1. Naskah yang akan diterbitkan harus sudah disubmit via ojs (bukan via email) paling lambat 2 bulan sebelum jadwal penerbitan (maksimal Januari untuk terbitan Maret, dan Agustus untuk terbitan Oktober).

2. Jika sebelum deadline 2 bulan tersebut kuota artikel untuk satu terbitan telah terpenuhi (maksimal 25 artikel per terbitan), maka naskah yang masuk berikutnya akan dipertimbangkan untuk direview pada terbitan selanjutnya.

3. Prioritas naskah yang diterbitkan dipertimbangkan berdasarkan urutan submit, kebaruan penelitian, kecepatan revisi dan pembayaran, serta distribusi institusi dan wilayah asal 
penulis.

4. Jika terdapat 2 atau lebih naskah yang dikirimkan oleh penulis yang sama (baik itu sebagai penulis pertama maupun penulis berikutnya), maka hanya salah satu naskah yang akan masuk ke tahap review.

5. Penulis diharapkan memantau status artikel via web dan mengecek inbox/spam email secara reguler jika artikel telah masuk tahap review.

6. Silakan masukkan alamat lengkap dan nomor ponsel pada Bio Statement di bagian profil untuk memudahkan komunikasi dan distribusi pengiriman naskah cetak.

\section{ACCREDITATION}

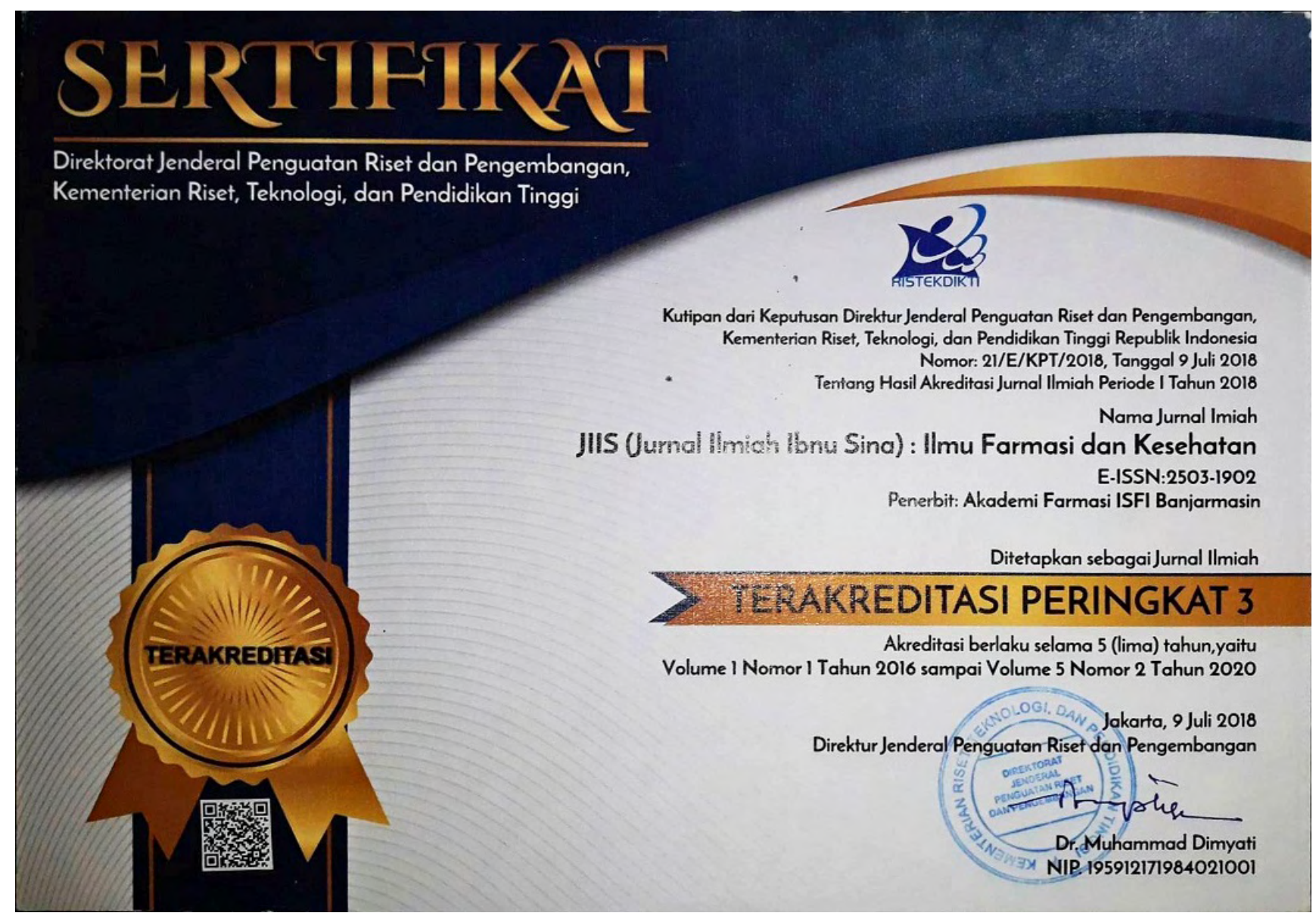

\section{VISITOR}

\section{Visitors}

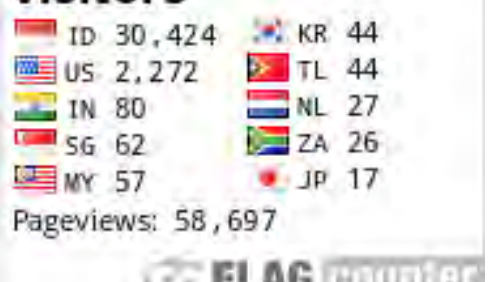


Make a Submission

\section{JOURNAL TEMPLATE}

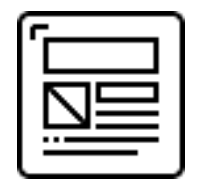

TOOLS

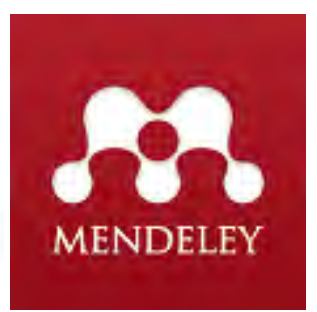

INDEXED BY:

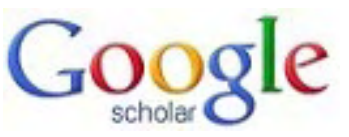

BASE

Ondononearch

Cisinta

C) GARUDA

\section{Crossref}

p-ISSN: 2502-647X; e-ISSN: 2503-1902 


\section{Redaksi Jurnal Ilmiah Ibnu Sina}

$\underline{\text { Akademi Farmasi ISFI Banjarmasin }}$

Jl. Flamboyan III/7b Kayu Tangi 70123

Banjarmasin Kalimantan Selatan

Telepon: (0511)-3301610, 3300221

Email: jiis@akfar-isfibjm.ac.id

\section{Platform \& workflow by OJS / PKP}




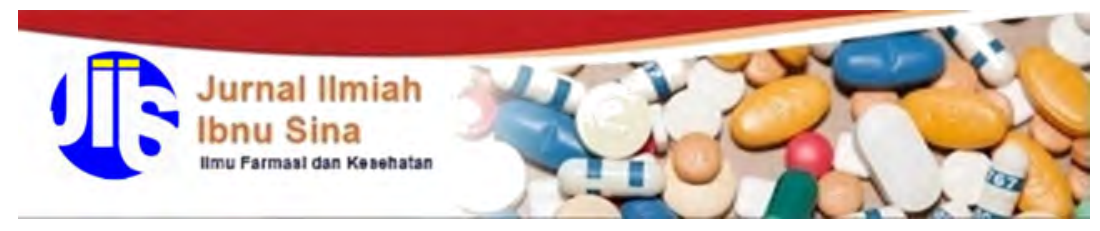

Archives Announcements Editorial Team Submissions About

\title{
PENGARUH PENGETAHUAN-SIKAP MENGENAI VITAMIN D TERKAIT OBESITAS PADA MAHASISWA
}

\author{
Amelia Lorensia \\ Departemen Farmasi Klinis-Komunitas, Fakultas Farmasi, Universitas Surabaya \\ Dian Natasya Raharjo \\ Departemen Farmasi Klinis-Komunitas, Fakultas Farmasi, Universitas Surabaya
}

Novelia Gandawari

Fakultas Farmasi, Universitas Surabaya

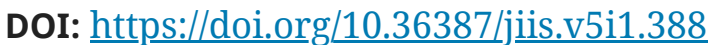

Keywords: Knowledge, attitude, vitamin D, obesity, adult

\begin{abstract}
Indonesia as a tropical country has a tendency to experience vitamin D deficiency. Knowledge and attitudes towards sun exposure contribute to the risk of vitamin D deficiency. In the midst of urban life patterns, obesity also increases the risk of vitamin D deficiency. This study was conducted to determine the effect of the level of knowledge and attitudes regarding vitamin D related to obesity in adults, which was conducted in March 2018 to January 2019. The study used a cross sectional design, with a knowledge and attitude questionnaire regarding vitamin D. Respondents were adults and domiciled in Surabaya , as many as 74 people in each group of obesity and non-obese. The results showed that obese and non-obese respondents both had good knowledge (OR 1.138) but had a bad attitude (OR 1,000). There was no significant difference in knowledge and attitudes in the two groups, and had a weak correlation.
\end{abstract}

\section{References}


Al-Mogbel, E.S. (2012) 'Vitamin D Status among Adults Saudi Females Visiting Primary Health Care Clinics', Int J Health Sci Qassim University, 6(2),pp.116-26.

American Skin Association. (2012) 'Sun Safety' (online), Available at:

http://www.americanskin.org/resource/safety.php [diakses 1 April 2018]

Arora, H., Dixit, V., Srivastava, N. (2016). 'Evaluation of Knowledge, Practice of Vitamin D and Attitide Toward Sunlight Among Indian Students', Asian Journal of Pharmaceutical Clinical Research, 9(1),pp.308-313.

Bolek-Berquist, J., Elliott, M.E., Gangnon, R.E., Gemar, D., Engelke, J., Lawrence, S.J., Hansen, K. (2009). 'Use of a Questionnaire to Assess Vitamin D Status in Young Adults', Public Health Nutrition, 12(2),pp.236-243.

Ernawati, F., Budiman, B. (2015). 'Status Vitamin D terkini Anak Indonesia', SEANUTS, 38(1),pp.7380 .

Fleury, N., Geldenhuys, S., Gorman, S. (2016). 'Sun Exposure and Its Effects on Human Health: Mechanisms through Which Sun Exposure Could Reduce the Risk of Developing Obesity and Cardiometabolic Dysfunction', Int J Environ Res Public Health, 13(10),pp.999.

Kung, A., Lee, K.K. (2006). 'Research article: Knowledge of vitamin D and perceptions and attitudes toward sunlight among Chinese middle-age and elderly women: a population survey in Hong Kong, BMC Public Health, 7(6),pp.226.

Muhairi, S.J., Mehairi, A.E., Khouri, A.A., Naqbi, M.M., Maskari, F.A., Al-Kaabi, J., Al-Dhaheri, A.S., Nagelkerke, N., Shah, S.M. (2013). 'Vitamin Deficiency Among Healthy Adolescents in Al Ain, United Arab Emirates’, BMC Public Health, 13(33),pp.1-7.

Nair, R., Arun, M. (2012). 'Vitamin D: The “Sunshine” Vitamin', J Pharmacol Pharmacother, 3(2),pp.118-126.

Nimitphong, H., Holick, M.F. (2013). 'Vitamin D status and sun exposure in Southeast Asia', Department of Medicine Dermato-Endocrinology, 5(1),pp.34-37.

Pengpid, S., Peltzer, K. (2015). 'Sun Protection Use Behaviour Among University Studens from 25 Low, Middle Income and Emerging Economy Countries', Asiean Pasific Journal of Cancer Prevention, 16(4),pp.1385-9.

Qureshi, A.Z., Zia, Z., Gitay, M.N., Khan, M.U., Khan, M.S. (2015). 'Attitude of future healthcare provider towords vitamin D significance in relation to sunlight exposure', Saudi Pharmaceutical Journal, 23(5),pp.523-527.

Sunita, A. (2010). Prinsip Dasar Ilmu Gizi. Jakarta: Gramedia Pustaka Utama.p.167-173. 
Suryadinata, R.V., Lorensia, A., Aprilia, A.P. (2017). 'Profil Vitamin D pada Pasien Asma dan NonAsma Dewasa di Surabaya’, The Indonesian Journal of Public Health, 12(1),pp.106-117.

Vanlint, S. (2013). 'Vitamin D and Obesity’. Nutrien, 5(3),pp.949-956.

Vimaleswaran, K.S., Berry, D.J., Lu, C., Tikkanen, E., Pilz, S., Hiraki, L.T., et al. (2013). ‘Causal Relationship between Obesity and Vitamin D Status: Bi-Directional Mendelian Randomization Analysis of Multiple Cohorts', PLOS Medicine, 10 (2),pp.e1001383.

Walker, N., Thomas, D.L., Dane, F.B., Phillip, B.H., Jillian, H., Antony, S.E., Katherine, E.B. (2014). 'Knowledge and attitudes to vitamin D and sun exposure in elite New Zealand athletes: a crosssectional study', Journal of the international society of sports nutrition, 11(47),pp.1-6.

WHO. (2016) 'Obesity Adults' (Online) Available at:

http://www.who.int/mediacentre/factsheets/fs311/en/ [diakses 1 April 2018]

Zhou, M., Zhuang, W., Yuan, Y., Li, Z., Cai, Y. (2016). 'Investigation on Vitamin D Knowledge, Attitude and Practice of University Students in Najing, China', Public Health Nutrition, 19(1),pp.7882. 


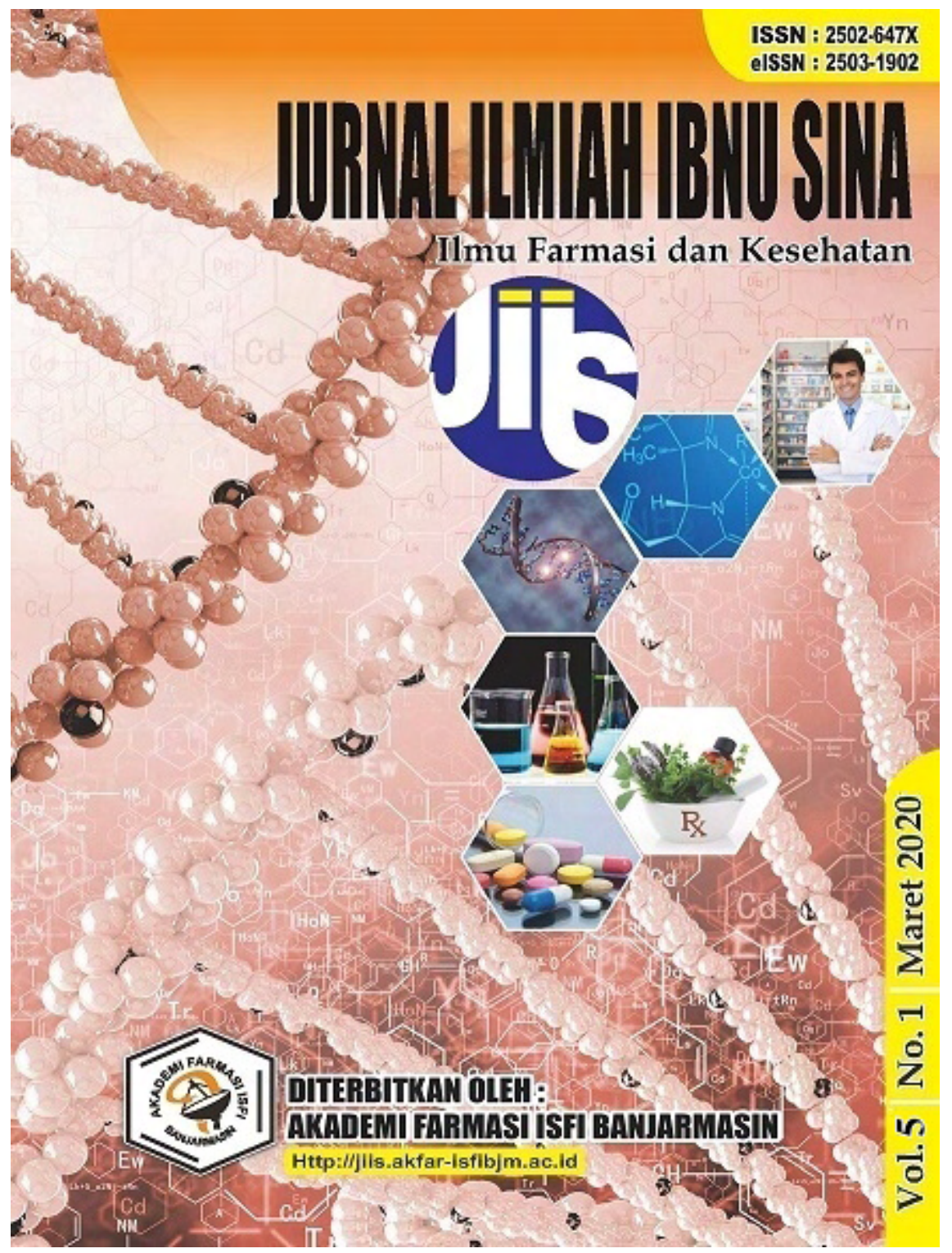

园 PDF (Bahasa Indonesia)

Published

2020-03-30

How to Cite

Lorensia, A., Raharjo, D., \& Gandawari, N. (2020). PENGARUH PENGETAHUAN-SIKAP MENGENAI VITAMIN D TERKAIT OBESITAS PADA MAHASISWA. Jurnal Ilmiah Ibnu Sina, 5(1), 72-86. https://doi.org/10.36387/jiis.v5i1.388

More Citation Formats

Issue

Vol 5 No 1 (2020).

\section{Section}

Artikel 
Copyright (c) 2020 Jurnal Ilmiah Ibnu Sina

\section{(c) (i)}

This work is licensed under a Creative Commons Attribution-NonCommercial-ShareAlike 4.0 International License.

\section{ACCREDITATION}

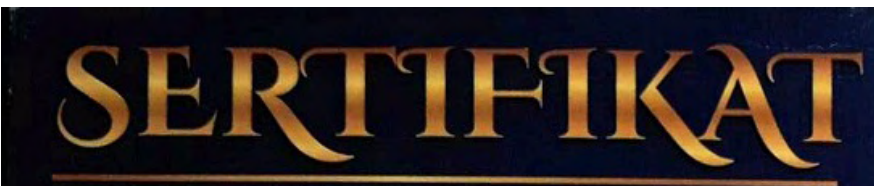

Direktorat Jenderal Penguatan Riset dan Pengembangan,

Kementerian Riset, Teknologi, dan Pendidikan Tinggi

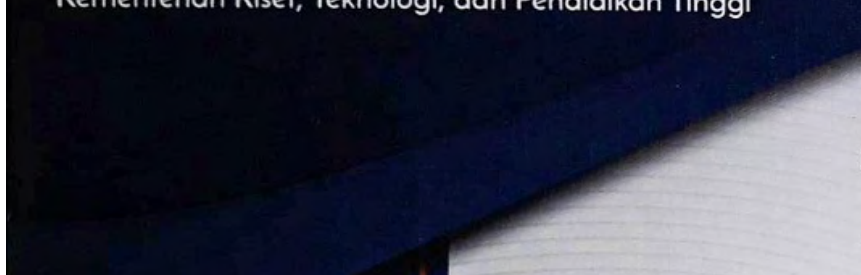
Kementerian Riset, Teknologi, dan Pendidikan Tinggi Republik Indonesia Nomor: 21/E/KPT/2018, Tanggal 9 Juli 2018 Tentang Hasil Akreditasi Jurnal Ilmiah Periode I Tahun 2018

Nama Jurnal Imiah

JIS (Jurnal Ilmich lbnu Sina) : Ilmu Farmasi dan Kesehatan E-ISSN:2503-1902 Penerbit: Akademi Farmasi ISFI Banjarmasin

Ditetapkan sebagai Jurnal Ilmiah

\section{TERAKREDITASI PERINGKAT 3}

Akreditasi berlaku selama 5 (lima) tahun, yaitu Volume I Nomor 1 Tahun 2016 sampai Volume 5 Nomor 2 Tahun 2020

$$
\text { LOGI. } 04 \text { / Jakarta, } 9 \text { Juli } 2018
$$
Direktur Jenderal Penguatan Riset dan Pengembangan

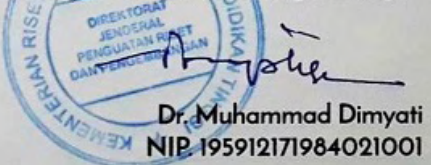

\section{VISITOR}

\section{Visitors}

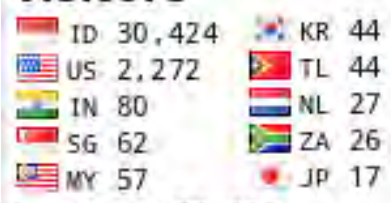

Pageviews: 58,697

NIP 195912171984021001 
Make a Submission

JOURNAL TEMPLATE

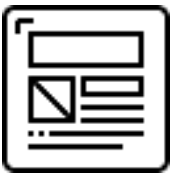

TOOLS
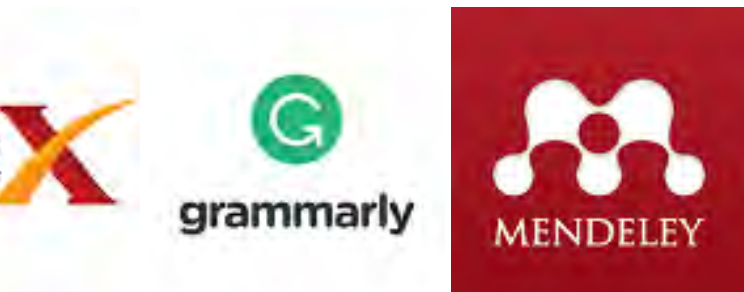

INDEXED BY:
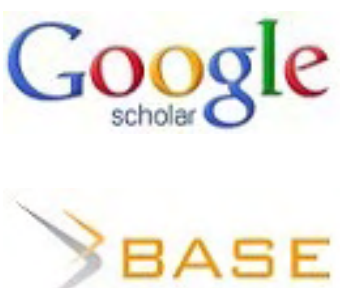

Onênearch

Csinta

C GARUDA

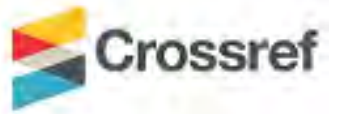

p-ISSN: 2502-647X; e-ISSN: 2503-1902 


\section{Redaksi Jurnal Ilmiah Ibnu Sina}

$\underline{\text { Akademi Farmasi ISFI Banjarmasin }}$

Jl. Flamboyan III/7b Kayu Tangi 70123

Banjarmasin Kalimantan Selatan

Telepon: (0511)-3301610, 3300221

Email: jiis@akfar-isfibjm.ac.id

\section{Platform \& workflow by OJS / PKP}

